\title{
Influence of Sowing Time and Integrated Nitrogen Management on Growth and Yield of Local Glutinous Maize (Zea mays L.)
}

\author{
Tabuiliu Abonmai*, Edwin Luikham, Kazamba Kamwenu and Kumar Sambhav Giri \\ Department of Agronomy, College of Agriculture, Central Agricultural University, \\ Imphal-795004, Manipur, India \\ *Corresponding author
}

\section{A B S T R A C T}

\begin{tabular}{|l|}
\hline Key w or d s \\
Local glutinous \\
maize, Sowing \\
time, INM, Growth, \\
Yield and yield \\
attributes
\end{tabular}

A field experiment was conducted during the pre-kharif season of 2018 at experimental field of College of Agriculture, Central Agricultural University, Imphal, Manipur to study the influence of sowing time and integrated nitrogen management on growth and yield of local glutinous maize (Zea mays L.). The experiment was laid out in factorial randomized block design (FRBD) with 12 treatments and 3 replications. The treatment consisted of four different integrated nitrogen management practices and three sowing dates. The result revealed that maximum plant height, plant fresh weight, number of leaves and LAI were recorded with the application of RDN- 75\% through urea + 25\% through FYM $\left(\mathrm{N}_{3}\right)$ for the crop sown on $9^{\text {th }}$ April $\left(\mathrm{S}_{3}\right)$. Similarly maximum number of cobs per plant, number of grain rows per cob, cob length, number of grains per cob and test weight of maize was observed in the treatment $\mathrm{N}_{3} \mathrm{~S}_{3}$. The maximum grain and stover yield were obtained with the application of RDN- $75 \%$ through urea $+25 \%$ through FYM and the crop sown on $9^{\text {th }}$ April. It can be concluded that the local glutinous maize (Zea mays L.) responded well to the integrated nitrogen management for the crop sown on $9^{\text {th }}$ April $\left(\mathrm{N}_{3} \mathrm{~S}_{3}\right)$ as expressed in growth and yield.

\section{Introduction}

Maize (Zea mays L.) is one of the most important cereal crops in the world's agricultural economy both as food for man and feed for animals. Maize has been an important cereal crop owing to its highest production potential and adaptability to wide range of environment hence called as 'Queen of Cereals' (Choudhari and Channappagouda, 2015). It can be grown in kharif, rabi and summer seasons. Over 85 per cent of maize production in country is consumed as a source of human feed. Maize is grown in almost all the states of India and it occupy an area of about 9.86 million hectares with a production of 26.26 million tonnes and productivity of 2664 kg/ha (Anon., 2017). In Manipur, it covers an area of 26.19 thousand hectares with a production of 57.94 MT and productivity of $2240 \mathrm{~kg} / \mathrm{ha}$ (Anon., 2016-17).

Local glutinous maize is popular and commonly grown cultivar in Manipur. It has 
unique characteristic of soft and stickiness of kernel even though it is dried and stored for long time unlike the normal maize. The local glutinous maize also fetches higher price in the local market as compared to the normal high yielding and hybrid maize. Among the agro-techniques non-monetary inputs like sowing time and nutrient are the two management aspects to be considered for improving the yield of maize.

Sowing at the right time will expose the maize crop to suitable weather elements required at different phenological stages resulting in better vegetative growth and yield. There are several factors like climate, nutrient availability and agronomic management practices including sowing time which affects the productivity of maize. In order for crops to best utilize moisture, nutrients and solar radiation, sowing must be done at optimum time.

Maize is a heavy feeder and remove large amount of nutrients from soil hence there is a need for proper and efficient nutrient management to harness the maximum yield potential of the crop. Continuous use of only chemical fertilizers in intensive cropping system will lead to imbalance of nutrients in soil, which has an adverse effect on soil health and also on crop yield. Again the use of organic manure (FYM) alone does not result in spectacular increase in crop yield, due to their low nutrient status.

In view to the declining productivity levels, increasingly greater emphasis is now being given to the integrated nitrogen supply system, which may play an important role in sustaining soil conditions. Thus highest productivity of crops in sustainable manner without deteriorating the soil and other natural resources could be achieved only by applying appropriate combination of different organic manures and inorganic fertilizers.

\section{Materials and Methods}

The field experiment was undertaken during the pre-kharif season of 2018 at College of Agriculture, CAU, Imphal, Manipur to study the influence of sowing time and integrated nitrogen management on growth and yield of local glutinous maize (Zea mays L.).

The experiment was laid out in factorial randomized block design (FRBD) with 12 treatments and 3 replications. The treatment consisted of four different integrated nitrogen management treatments and three sowing dates. FYM was applied 20 days before sowing as per treatment and well incorporated to the soil. Required quantities of nitrogen in the form of urea $(46 \% \mathrm{~N})$ and uniform dose of $30 \mathrm{~kg} \mathrm{P}_{2} \mathrm{O}_{5} / \mathrm{ha}$ in the form of single superphosphate $\left(\begin{array}{llll}16 \% & \mathrm{P}_{2} \mathrm{O}_{5}\end{array}\right)$ and $20 \mathrm{~kg}$ $\mathrm{K}_{2} \mathrm{O} /$ ha in the form of muriate of potash $(60 \%$ $\mathrm{K}_{2} \mathrm{O}$ ) were applied one day before sowing of crop to the respective plots a basal dose and the remaining dose of nitrogen was top dressed in two equal splits at knee high stage and tasseling stage. Measurements on growth attributing parameters were recorded at 25 days interval from sowing till harvest.

Treatment details

Sowing time: 3

$\mathrm{S}_{1}-1^{\text {st }}$ March

$\mathrm{S}_{2}-20^{\text {th }}$ March

$\mathrm{S}_{3}-9^{\text {th }}$ April

Nitrogen management: 4

$\mathrm{N}_{1}-\mathrm{RDN}(100 \%$ through urea)

$\mathrm{N}_{2}-\mathrm{RDN}$ (50\% through urea $+50 \%$ through FYM)

$\mathrm{N}_{3}-\mathrm{RDN}(75 \%$ through urea $+25 \%$ through FYM) 
$\mathrm{N}_{4}-\mathrm{RDN}(100 \%$ through FYM)

\section{Results and Discussion}

Effect of sowing time and integrated nitrogen management on growth of local glutinous maize

The growth of local glutinous maize was significantly influenced by different nitrogen management practices and sowing time and presented in Table 1. The maximum plant height was recorded in nitrogen management $\mathrm{N}_{3}$. This finding is also supported by Rasool et al., (2015) and Singh et al., (2018). The beneficial effect of incorporation of FYM and nitrogen on plant height of maize was also reported by Oad et al., (2004), Karki et al., (2005) and Tetarwal et al., (2011). Among the different integrated nitrogen management, the highest plant dry weight was observed in treatment $\mathrm{N} 3$ which remained at par to $\mathrm{N}_{2}$ at 25 DAS but significantly superior at 50, 75, 100 DAS and at harvest. Integrated nitrogen management facilitated better nutrient and soil moisture absorption by plants and it enhanced the photosynthesis and translocation of the metabolites to different plant parts.

The findings are in agreement with those of Sepat and Kumar (2007), Jadhav (2010), Rasool et al., (2015), and Singh et al., (2018) in maize. It is found that the maximum dry matter accumulation per plant was the positive effect of growth characters. Application of integrated nitrogen enhanced significantly the leaf area index of the plant over application of either fertilizer or organic manures alone. At 25 and 50 DAS, the significantly higher LAI was observed in treatment $\mathrm{N}_{3}$ which remained at par to treatment $\mathrm{N}_{2}$. In the succeeding three stages, maximum LAI was recorded in $\mathrm{N}_{3}$ and it showed significant superiority over the other treatments. Similar finding was also reported by Sepat and Kumar (2007), Jadhav (2010) and Rasool et al., (2015).
Different sowing time significantly influencethe growth of local glutinous maize. Significantly highest plant height was observed in $9^{\text {th }}$ April $\left(\mathrm{S}_{3}\right)$ sowing which remained at par to $20^{\text {th }}$ March $\left(\mathrm{S}_{2}\right)$ sown plants. It enhanced the plant height with respective sowing date due to optimum sowing time and favourable climatic conditions. The variation in plant height with different sowing time was also reported by Verma (2013) and Sulochana et al., (2015) in maize. The maximum plant dry weight was obtained in $9^{\text {th }}$ April $\left(\mathrm{S}_{3}\right)$ sowing which remained at par to $20^{\text {th }}$ March $\left(\mathrm{S}_{2}\right)$ sown plants. Variation in dry weight of plant among different sowing time was supported by LawOgbomo and Remison (2009), Sulochana et al., (2015) and Keerthi and Reddy (2017). Highest LAI was observed in $9^{\text {th }}$ April $\left(\mathrm{S}_{3}\right)$ sowing which remained at par to $20^{\text {th }}$ March $\left(\mathrm{S}_{2}\right)$ sowing but significantly higher to $1^{\text {st }}$ March $\left(\mathrm{S}_{1}\right)$ sowing. It enhanced the leaf area index resulting in more photosynthesis, which improved the growth, development and dry matter production per plant with respective date of sowing due to optimum sowing time, favourable climatic conditions especially temperature and suitable growth period. Such variation in leaf area index among different sowing time was supported by Law-Ogbomo and Remison (2009) and Sulochana et al., (2015).

The interaction between sowing time and integrated nitrogen management could not give significant effect on growth parameters.

Effect of sowing time and integrated nitrogen management on yield contributing factors of local glutinous maize

Integration of inorganic fertilizer and FYM influenced the total number of cobs per plant, number of grain rows per cob, length of cob, number of grain rows per cob and test weight and are presented in Table 2. 
Table.1 Effect of sowing time and integrated nitrogen management on growth of local glutinous maize

\begin{tabular}{|c|c|c|c|c|c|c|c|c|c|c|c|c|c|c|c|}
\hline \multirow[t]{2}{*}{ Treatment } & \multicolumn{5}{|c|}{ Plant height (cm) } & \multicolumn{5}{|c|}{ Dry matter production (g/plant) } & \multicolumn{5}{|c|}{ LAI } \\
\hline & $\begin{array}{c}25 \\
\text { DAS }\end{array}$ & $\begin{array}{c}50 \\
\text { DAS }\end{array}$ & $\begin{array}{c}75 \\
\text { DAS }\end{array}$ & $\begin{array}{c}100 \\
\text { DAS }\end{array}$ & $\begin{array}{l}\text { HARV } \\
\text { EST }\end{array}$ & $\begin{array}{c}25 \\
\text { DAS }\end{array}$ & $\begin{array}{c}50 \\
\text { DAS }\end{array}$ & $\begin{array}{c}75 \\
\text { DAS }\end{array}$ & $\begin{array}{c}100 \\
\text { DAS }\end{array}$ & $\begin{array}{c}\text { HARVE } \\
\text { ST }\end{array}$ & $\begin{array}{c}25 \\
\text { DAS }\end{array}$ & $\begin{array}{c}50 \\
\text { DAS }\end{array}$ & $\begin{array}{c}75 \\
\text { DAS }\end{array}$ & $\begin{array}{c}100 \\
\text { DAS }\end{array}$ & $\begin{array}{c}\text { HARV } \\
\text { EST }\end{array}$ \\
\hline \multicolumn{16}{|c|}{ S: Sowing time } \\
\hline $\mathbf{S}_{1}$ & 12.75 & 34.86 & 135.85 & 188.77 & 231.75 & 0.13 & 11.18 & 20.10 & 53.48 & 96.55 & 0.34 & 1.27 & 1.57 & 1.95 & 1.10 \\
\hline $\mathbf{S}_{2}$ & 14.19 & 48.87 & 141.12 & 193.73 & 235.06 & 0.18 & 11.74 & 22.01 & 58.51 & 100.33 & 0.45 & 1.64 & 1.91 & 2.60 & 1.27 \\
\hline $\mathbf{S}_{3}$ & 16.57 & 60.93 & 144.39 & 197.67 & 236.67 & 0.21 & 12.34 & 22.65 & 60.44 & 102.04 & 0.57 & 2.22 & 2.24 & 2.70 & 1.32 \\
\hline SE d ( $( \pm)$ & 0.63 & 1.83 & 1.75 & 2.08 & 1.36 & 0.011 & 0.25 & 0.77 & 1.16 & 0.84 & 0.02 & 0.08 & 0.07 & 0.05 & 0.03 \\
\hline $\begin{array}{c}\text { CD } \\
(\mathbf{P}=0.05)\end{array}$ & 1.31 & 3.80 & 3.64 & 4.32 & 2.81 & 0.02 & 0.51 & 1.61 & 2.40 & 1.74 & 0.04 & 0.17 & 0.16 & 0.11 & 0.07 \\
\hline \multicolumn{16}{|c|}{$\mathrm{N}$ management } \\
\hline $\mathbf{N}_{1}$ & 13.91 & 46.35 & 136.07 & 189.38 & 233.16 & 0.16 & 11.30 & 20.56 & 55.82 & 95.69 & 0.44 & 1.61 & 1.79 & 2.34 & 1.23 \\
\hline $\mathbf{N}_{2}$ & 15.02 & 50.12 & 147.22 & 197.80 & 236.85 & 0.18 & 12.18 & 22.68 & 61.18 & 105.89 & 0.47 & 1.77 & 1.99 & 2.54 & 1.32 \\
\hline $\mathbf{N}_{3}$ & 15.95 & 53.34 & 151.91 & 204.45 & 241.45 & 0.20 & 13.07 & 24.72 & 66.06 & 108.97 & 0.50 & 1.89 & 2.25 & 2.75 & 1.44 \\
\hline $\mathbf{N}_{4}$ & 13.14 & 43.07 & 126.62 & 181.92 & 226.51 & 0.15 & 10.47 & 18.39 & 46.84 & 87.46 & 0.41 & 1.57 & 1.59 & 2.04 & 0.93 \\
\hline SE d ( $( \pm)$ & 0.73 & 2.11 & 2.03 & 2.40 & 1.57 & 0.01 & 0.28 & 0.89 & 1.34 & 0.97 & 0.02 & 0.09 & 0.09 & 0.06 & 0.04 \\
\hline $\begin{array}{c}\text { CD } \\
(\mathbf{P}=0.05)\end{array}$ & 1.51 & 4.38 & 4.20 & 4.99 & 3.25 & 0.02 & 0.59 & 1.85 & 2.77 & 2.01 & 0.05 & 0.19 & 0.18 & 0.12 & 0.08 \\
\hline
\end{tabular}

Table.2 Effect of sowing time and integrated nitrogen management on yield contributing factors of local glutinous maize

\begin{tabular}{|c|c|c|c|c|c|}
\hline Treatment & $\begin{array}{c}\text { No. of } \\
\text { cobs/plant }\end{array}$ & $\begin{array}{l}\text { No. of grain } \\
\text { row/cob }\end{array}$ & $\begin{array}{l}\text { Cob length } \\
\quad(\mathrm{cm})\end{array}$ & $\begin{array}{c}\text { No. of } \\
\text { grains/cob }\end{array}$ & $\begin{array}{c}\text { Test weight } \\
\text { (g) }\end{array}$ \\
\hline \multicolumn{6}{|c|}{ S: Sowing time } \\
\hline $\mathbf{S}_{1}$ & 1.20 & 14.17 & 14.6 & 272.58 & 247.08 \\
\hline $\mathbf{S}_{\mathbf{2}}$ & 1.30 & 15.04 & 15.2 & 289.00 & 250.17 \\
\hline $\mathbf{S}_{\mathbf{3}}$ & 1.35 & 15.44 & 15.5 & 292.75 & 253.08 \\
\hline SE d ( \pm$)$ & 0.06 & 0.32 & 0.23 & 2.86 & 2.31 \\
\hline $\mathrm{CD}(\mathrm{P}=0.05)$ & NS & 0.66 & 0.48 & 5.93 & NS \\
\hline \multicolumn{6}{|c|}{$\mathrm{N}$ management } \\
\hline $\mathbf{N}_{1}$ & 1.27 & 14.41 & 14.75 & 262.56 & 248.00 \\
\hline $\mathbf{N}_{2}$ & 1.33 & 15.37 & 15.91 & 312.33 & 253.89 \\
\hline $\mathbf{N}_{3}$ & 1.38 & 16.25 & 16.97 & 337.89 & 257.00 \\
\hline $\mathbf{N}_{4}$ & 1.16 & 13.51 & 12.76 & 226.33 & 241.56 \\
\hline SE d $( \pm)$ & 0.07 & 0.37 & 0.27 & 3.30 & 2.67 \\
\hline $\mathrm{CD}(\mathrm{P}=0.05)$ & 0.15 & 0.76 & 0.56 & 6.84 & 5.53 \\
\hline
\end{tabular}


Table.3 Effect of sowing time and integrated nitrogen management on grain yield, stover yield and harvest index of local glutinous maize

\begin{tabular}{|c|c|c|c|}
\hline Treatment & $\begin{array}{l}\text { Grain yield } \\
\text { (q/ha) }\end{array}$ & $\begin{array}{l}\text { Stover yield } \\
\text { (q/ha) }\end{array}$ & $\begin{array}{c}\text { Harvest index } \\
(\%)\end{array}$ \\
\hline \multicolumn{4}{|c|}{ S: Sowing time } \\
\hline $\mathbf{S}_{1}$ & 25.65 & 52.12 & 32.85 \\
\hline $\mathbf{S}_{2}$ & 27.49 & 55.40 & 32.98 \\
\hline $\mathbf{S}_{3}$ & 28.23 & 57.49 & 32.75 \\
\hline SE d ( \pm$)$ & 0.38 & 1.25 & 0.41 \\
\hline $\mathrm{CD}(\mathbf{P}=\mathbf{0 . 0 5})$ & 0.78 & 2.58 & NS \\
\hline \multicolumn{4}{|c|}{$\mathrm{N}$ management } \\
\hline$N_{1}$ & 24.67 & 51.81 & 32.29 \\
\hline $\mathbf{N}_{2}$ & 30.15 & 58.74 & 33.92 \\
\hline $\mathbf{N}_{3}$ & 32.90 & 62.53 & 34.49 \\
\hline $\mathbf{N}_{4}$ & 20.78 & 46.92 & 30.73 \\
\hline SE d ( \pm$)$ & 0.44 & 1.44 & 0.47 \\
\hline $\mathrm{CD}(\mathrm{P}=0.05)$ & 0.91 & 2.98 & 0.98 \\
\hline
\end{tabular}

The highest number of cobs per plant (1.38) was recorded with treatment $\mathrm{N}_{3}$ which remained at par to treatment $\mathrm{N}_{2}$. The increase in number of cobs might be due to adequate supply of nitrogen and uptake by the plants. Similar finding was also reported by Mehta $e t$ al., (2005) and Jadhav (2010). The mean number of grain rows per cob (16.25) was maximum due to application of $\mathrm{RDN}-75 \%$ through urea $+25 \%$ through FYM $\left(\mathrm{N}_{3}\right)$ and showed its significant superiority over the rest of the treatments. The findings are in agreement with those of Mehta et al., (2005), Rajeshwari et al., (2007) and Jadhav (2010). The mean cob length was maximum (16.97 $\mathrm{cm})$ and significantly more when crop was fertilized with RDN- 75\% through urea + $25 \%$ through FYM $\left(\mathrm{N}_{3}\right)$. The results are in accordance with the earlier finding of Kumar and Puri (2001) and Rajeshwari et al., (2007). The number of grains per cob (337.89) was significantly higher in treatment $\mathrm{N}_{3}$ compared to other treatments. The increase in yield attributes might have been owing to better utilization of resources under improved $\mathrm{N}$ supply, as it is an integral part of proteins the building blocks of plant (Singh et al., 2000).
These findings are also supported by Rajeshwari et al., (2007) and Jadhav (2010). The maximum test weight (257) was recorded with the application of RDN- 75\% through urea $+25 \%$ through FYM $\left(\mathrm{N}_{3}\right)$ which remained at par to $\mathrm{N}_{2}$. The results are in accordance with the earlier findings of Balai (2007) and Jadhav (2010).

Though the highest number of cobs per plant (1.35) was observed at $9^{\text {th }}$ April sowing $\left(\mathrm{S}_{3}\right)$ however the differences with $20^{\text {th }}$ March $\left(\mathrm{S}_{2}\right)$ and $1^{\text {st }}$ March sowing $\left(\mathrm{S}_{1}\right)$ was found to be not significant. The variation among different sowing time was also reported by Awasthi (2009). The highest number of grain rows per cob (15.44) was recorded at $9^{\text {th }}$ April sowing $\left(\mathrm{S}_{3}\right)$ and it remained at par to sowing at $20^{\mathrm{th}}$ March $\left(\mathrm{S}_{2}\right)$. The highest mean cob length $(15.5 \mathrm{~cm})$ was recorded at $9^{\text {th }}$ April sowing $\left(\mathrm{S}_{3}\right)$ and it remained at par to $20^{\text {th }}$ March sowing $\left(\mathrm{S}_{2}\right)$. The number of grains per cob (292.75) was significantly higher in $9^{\text {th }}$ April sowing $\left(\mathrm{S}_{3}\right)$ however the number of grains per cob did not differ significantly between $\mathrm{S}_{3}$ and $\mathrm{S}_{2}$. This could be due to the better growth and development of $9^{\text {th }}$ April $\left(\mathrm{S}_{3}\right)$ sown crop. Such 
variation among different sowing time was also reported by Awasthi (2009) and Keerthi et al., (2017)

The interaction between sowing time and integrated nitrogen management could not bring significant effect on yield attributes.

Effect of sowing time and integrated nitrogen management on grain yield, stover yield and harvest index of local glutinous maize

Integrated nitrogen management and different sowing time significantly influenced the grain and stover yield and are presented in Table 3. The highest grain yield (32.9 q/ha) and stover yield $(62.53 \mathrm{q} / \mathrm{ha})$ was recorded in treatment $\mathrm{N}_{3}$ where RDN- $75 \%$ through urea+ $25 \%$ through FYM was applied. Owing to higher values of growth and yield attributes, the maximum grain yield was obtained in treatment $\mathrm{N}_{3}$. The improved physical properties like water holding capacity and moisture retention provided a desirable soil condition for the root development, enhanced crop growth and yield (Selvi et al., 2005). Similar findings were also reported by Rajeshwari et al., (2007) and Jadhav (2010). The harvest index was significantly higher in treatment $\mathrm{N}_{3}$ which remained at par to treatment $\mathrm{N}_{2}$. The significantly higher harvest index under treatment $\mathrm{N}_{3}$ was due to relatively greater seed yield than the remaining treatment. Similar results had also been reported by Kumar and Puri (2001) and Singh et al., (2018).

Among the sowing dates, it could be seen from Table 3 that though sowing at 9th April $\left(\mathrm{S}_{3}\right)$ recorded the maximum grain yield $(28.23$ $\mathrm{q} / \mathrm{ha}$ ) and stover yield (57.49 q/ha) however it remained at par to sowing on $20^{\text {th }}$ March $\left(\mathrm{S}_{2}\right)$ but was significantly superior over sowing at 1st March $\left(\mathrm{S}_{1}\right)$. The variation in among different sowing time was also supported by
Taipodia and Shukla (2013), Verma (2013) and Sulochana et al., (2015). The harvest index did not differ significantly among the different sowing dates.

The interaction between sowing time and integrated nitrogen management could not bring significant effect on yield.

\section{Acknowledgement}

The authors acknowledge the contributions of Tabuiliu Abonmai, Edwin Luikham, Kamwenu Kazamba and Kumar Sambhav Giri, Department of Agronomy, College Of Agriculture, Central Agricultural University, Imphal, Manipur (India) for their technical support and valuable contributions to the manuscript.

\section{References}

Anonymos (2016-17). Department of Agriculture, Manipur.

Anonymous (2017). Agric. Statistics at a Glance.

Awasthi, U.D., Kumar, K., Singh, M. and Kumar, S. (2009). Performance of maize (Zea mays) varieties under varying dates of sowing in prevailing agro-climatic condition of central Uttar Pradesh. Indian J. of Agric. Sci., 79(5): 385-387.

Balai, M.L. (2007). Productivity and quality of maize (Zea mays L.) as influenced by integrated nutrient management. Doctoral dissertation, MPUAT, Udaipur).

Choudhari, V.V. and Channappagouda, B.B. (2015). Effect of organics on morphophysiological traits and grain yield of maize (Zea mays L.). The Bioscan. 10(1): 339-341.

Jadhav, K.L. (2010). Effect of integrated nitrogen management on growth and seed yield of maize (Zea mays L.).Doctoral dissertation, MPKV, Rahuri.

Karki, T.B., Kumar, A. and Gautam, R.C. (2005). Influence of integrated nutrient management on growth, yield, content 
and uptake of nutrients and soil fertility status in maize (Zea mays). Indian $J$. Agric. Sci., 75(10): 682-685.

Keerthi, P. and Reddy, G.P. (2017). Growth and yield of sweet corn cultivars under different environmental conditions in southern agro-climatic zone of Andhra Pradesh. Environment and Ecology, 35(3A): 1826-1828.

Keerthi, P., Reddy, G.P. and Sunitha, N. (2017). Effect of sowing time on growth and yield of sweet corn cultivars. Int. J. Curr. Microbiol. App. Sci. 6(4): 777-782.

Kumar, P. and Puri, U.K. (2001).Effect of nitrogen and farmyard manure application on maize (Zea mays) varieties. Indian $J$. of Agron., 46(2): 255-259.

Law-Ogbomo, K.E. and Remison, S.U. (2009). Growth and yield of maize as influenced by sowing date and poultry manure application. Notulae Botanicae Horti Agrobotanici Cluj-Napoca, 37(1): 199203.

Mehta, Y.K., Shaktawat, M.S. and Singhi, S.M. (2005). Influence of sulphur, phosphorus and farm yard manure on yield attributes and yield of maize (Zea mays) in southern Rajasthan conditions. Indian J. Agron., 50(3): 202-205.

Oad, F.C., Buriro, U.A. and Agha, S.K. (2004). Effect of organic and inorganic fertilizer application on maize fodder production. Asian J. Plant Sci., 3(3): 375377.

Rajeshwari, R.S., Hebsur, N.S., Pradeep, H.M. and Bharamagoudar, T.D. (2007). Effect of integrated nitrogen management on growth and yield of maize. Karnataka $J$. Agric. Sci., 20(2): 399-400.

Rasool, S., Kanth, R.H., Hamid, S., Raja, W., Alie, B.A. and Dar, Z.A. (2015).
Influence of integrated nutrient management on growth and yield of sweet corn (Zea mays L. saccharata) under temperate conditions of Kashmir valley. American J. of Experimental Agriculture, 7(5): 315-325.

Selvi, D., Santhy, P. and Dhakshinamoorthy, M. (2005). Effect of inorganics alone and in combination with farm yard manure on physical properties and productivity of vertic Haplustepts under long term fertilization. J. Indian Soc. Soil Sci., 53(3): 302-307.

Sepat, S. and Kumar, A. (2007). Nitrogen management in maize (Zea mays) under lifesaving and assured irrigations.Indian J. Agric. Sci., 77(7): 451-454.

Singh, M., Kumar, R., Kumar, A., Jaswal, A. and Singh, A. (2018). Effect of combined use of organic and inorganic fertilizer sources on growth and yield of kharif maize in a coarse loamy typichaplustept soil. Plant Archives, 18(2): 1369-1372.

Sulochana, N.S., Dhewa, J.S. and Bajia, R. (2015). Effect of sowing dates on growth, phenology and agro meteorological indices for maize varieties. Bioscan, 10(3): 1339-1343.

Tetarwal, J.P., Ram, B. and Meena, D.S. (2011). Effect of integrated nutrient management on productivity, profitability, nutrient uptake and soil fertility in rainfed maize (Zea mays).Indian J. of Agron., 56(4): 373376.

Verma, N.K. (2013). Integrated nutrient management in winter maize (Zea mays L.) sown at different dates. J. of Plant Breeding and Crop Sci., 3(8): 161-167.

\section{How to cite this article:}

Tabuiliu Abonmai, Edwin Luikham, Kazamba Kamwenu and Kumar Sambhav Giri. 2019. Influence of Sowing Time and Integrated Nitrogen Management on Growth and Yield of Local Glutinous Maize (Zea mays L.). Int.J.Curr.Microbiol.App.Sci. 8(06): 2512-2518. doi: https://doi.org/10.20546/ijcmas.2019.806.301 